\title{
Review
}

\section{American Dionysia: Violence, tragedy and democratic politics}

\author{
Steven Johnston \\ Cambridge University Press, Cambridge, 2015, viii +296pp., \\ ISBN: 978-1107496675
}

Contemporary Political Theory (2016) 15, e40-e43. doi:10.1057/cpt.2016.6; advance online publication 23 February 2016

American Dionysia is a book about democracy. In it, Steven Johnston contends that democracy suffers from an eternal agony on account of its inherently tragic character. There is an ontological dimension to his tragic view, a dimension as omnipresent in the book as ontological claims typically demand. The cosmos is turbulent. Strife dominates life. Violence dominates the world. Enmity and death abound. This is the tragedy, and it requires no divine or transcendent context for it to materialize. When Johnston does write more narrowly about the tragedy of democracy, he is prone to deploy a terminology of metaphor, as though this political institution or system of government is a complex living organism with feelings, sensibilities and neurotic inclinations. Democracy comes alive, so to speak. Talk of democracy in terms of a system of political rule compatible with a variety of institutional structures or forms of legislative representation must have been prejudged, in conformity with a tragic perspective, as a ruse perpetrated by other political theorists to deny or disavow the tragic character of democracy. Johnston will have none of it. In reading through this bold and original book, one will find it difficult to beat back the suspicion that it would have been best if democracy had not been born, and next best for it to make haste to its own death.

However, this kind of gloomy message about democracy is not the message Johnston wants to convey. Yes, the author believes that democracy should cultivate a sensibility that appreciates the way that it breaks its own promises and perpetually spoils its own legitimacy. Democracy promises to transform the world through mutual self-rule, equality before the law, respect for difference, openness to plurality, and the security and dignity of all its citizens, but the violence and cruel exclusion constitutive of democracy ensures that it can never deliver in full. In no way does Johnston think that we can permanently alleviate the incessant agony that results from such broken promises. Instead, Johnston would institutionalize the task of cultivating a democracy that is worthy of

(C) 2016 Macmillan Publishers Ltd. 1470-8914 Contemporary Political Theory Vol. 15, 4, e40-e43 www.palgrave.com/journals 
reproaching itself even while it continues to pursue its own ideals with morally dubious means.

If readers are made aware of the 'brilliant failure' (p. 3) of democracy's aspirations (presumably these readers are the fundamental elements, if you will, that make up the life of democracy), new bursts of innovation might arise from this awareness, the kind capable of inspiring a sagacious fervor of adventure and daring. It is thus political wisdom, for Johnston, to anticipate inevitable violence, suffering and misfortune brought about by this innovative spirit. This wisdom is cast as a doubleedged weapon; it strives to remain conscious of the burdens of success and skilled in choosing sordid means to attain its ideals. Johnston proposes new public rituals and civic commemorations, with new or refurbished monuments and memorials, to force (American) democracy to critically reflect on itself. The author's model for such celebration qua criticism is the old festival of the Great or City Dionysia, invented by Athens some time around the fifth-century BCE. But unbridled patriotism insulates democracy from the tragic sensibility that Johnston seeks to animate with this new ritual. Patriotism is the recalcitrant menace of the book.

Chapter 1, 'American Dionysia', identifies Machiavelli, Nietzsche, Weber and Camus as part of a tradition that understands the tragic dynamism of democracy. This dynamism calls for the reinvention of the City Dionysia as an American film festival. John Ford's The Man Who Shot Liberty Valance is exemplary of the kind of tragic film Johnston imagines for such a festival. Chapter 2, 'Democracy at War with Itself: Citizens', explores how democracy induces a patriotic comportment that obstructs a tragic perspective. This time the 1982 film First Blood is exemplary. For Johnston, First Blood is a tragic horror film that dramatizes the self-destructive tendency of democracy manifest in the elemental citizens it inspires, governs and often destroys. It is important that we get the genre of the film right, says Johnston, since thinking about democracy and patriotism in the light of artistic genre can have ameliorative and creative effects. First Blood dramatizes the inherent villainy of democracy, shining light on how it routinely sends young men and women off to war, and if they are fortunate enough to return, how they find themselves unfit for the democracy they sought to preserve. Johnston proposes a formal day of confession: Admission Day. This day will place democracy's call on citizens to serve its regime in a register of ambiguity. The self-destructive tendencies become a source of national shame. This ambiguity is, Johnston admits, potentially dangerous, but it may energize its basic elements to adhere to its ideals with increased integrity. Johnston uses cautious language in saying that a democracy that encourages skepticism about itself may be the only one worth defending.

Chapter 3, 'Democracy at War with Itself: Animals', turns to a different dimension of democracy's monstrosity: the use of other species to defend its way of life. Johnston faults the Animals-in-War Memorial in London for leaving unexplored the tendency of democracy to annihilate animals in order to pursue its own wars. Johnston seizes on the lesson that animal resistance can offer during wartime, 
drawing briefly on a conception of life that posits resistance as its constitutive element and accentuating the active resistance of animals to the military projects of other species. For Johnston, however, the problem is that democracy tends to extirpate this resistance, even while it champions life and the freedom of resistance.

Chapter 4, 'Forcing Democracy to Be Free: Rousseau to Springsteen', looks to Rousseau's On the Social Contract for resources of creative destruction that might help save democracy from its own self-extirpation. The 'fabulous absence' (p. 123) of violence makes its presence felt in Rousseau's founding narrative, a violence that Johnston thinks will continue to haunt the tragic oscillation of life and death in democracy. The political challenge is to respond to this oscillation by first affirming the constitutive violence of democracy, and then become worthy of that affirmation. If democracy has a 'violence problem', it is not one to resolve by simply rejecting violent means; rather, the 'violence problem' is one of energizing its elements or citizens with the firm disposition they will need to deploy violent means for good ends. This is a tragic perspective that Johnston hears reverberating in the music of Bruce Springsteen. The protagonists in his music often turn to violence to achieve the justice that escapes them. This kind of violence is necessary, according to this tragic perspective, for democracy must accept responsibility for the inexorable destruction it brings about.

Chapter 5, 'Two Cheers for Democratic Violence', returns to the theme of patriotism. Johnston identifies a shortcoming in constitutional patriotism's commitment to violence, for at best such patriotism only flirts with the necessity of democratic violence. Constitutional patriotism ultimately rejects the necessity of violence, when it ought to be steadfastly affirmed. To show how democracy relies on a violence that it formally rejects, the author turns to Zal Batmanglij's 2013 film The East. The film tracks anti-corporate activists as they pursue violent strategies and bring attention to the immoral corporate practices as lethal as they are beyond the reach of law. The film spotlights a dynamic that contemporary theorists of violence like John Keane and John McCormick fail to pursue; these theorists ignore the way that democratic violence can attain a certain legitimacy. After all, and here Johnston tries to assure his readers, the reciprocal violence of corporations and anti-corporate activists can have its benefits.

Chapter 6, 'New Tragic Democratic Traditions', argues that democracy in America today suffers from excessive preoccupation with the Vietnam War and the attacks on 11 September 2001. The public commemorative rituals and memorial architecture create a culture of victimization and enmity, obstructing any serious consideration of the effects these events have had on democracy. They contribute to the obsessive narcissism of democracy that feeds on its own exceptionalism. The author proposes naming September 11th Democracy Day to acknowledge the political violence and resilience of democracy. For the monuments and memorials in Lower Manhattan and on the Mall in Washington DC, the author proposes renovations that will incorporate the perspective of the enemy who inspired them. 
The book's concluding section, 'Democracy's Tragic Affirmations', appeals to another western with a violent ending, Shane. Apparently, the film has resources for a political approach to the necessity of violence in democracy. The hero of the film is Joe, who we are told has the Weberian strength to pursue a one-eyed vision of democratic good, with the other eye focused on the tragic ambiguity that results from pursuing and realizing such a good. But there is at least one problem with this notion of tragic ambiguity. Johnston's creative reading of Sophocles' Oedipus Rex tries to illuminate the notion, though it actually misunderstands the ambiguity of tragic action. Johnston's reading considers Oedipus worthy of emulation, but this selfbanishing pollution does not merit emulation in the slightest, nor does he manage, even in some partial sense, to prevail over the prophecy of Apollo by affirming his life and his own sovereignty, as Johnston claims. Comparing Oedipus' refusal to follow the example of suicide set by Jocasta reveals nothing like a life-affirming resilience on the part of pitiful Oedipus; on the contrary, his self-incurred blinding exhibits his dramatic recognition of the divine curse that had always governed his actions. The act of refusing suicide expresses this recognition, and the ultimate surrender of the alleged sovereignty he never really possessed in the first place. At the end of the play, Oedipus recognizes that he is in no condition to rule. If democracy at all resembles the tragic ambiguity of Oedipus, then it would be better for our turbulent cosmos if democracy speedily emulates Jocasta's suicide rather than continue the tragedy of its rule.

Charles Snyder Bard College, Annandale-on-Hudson, NY 12504, USA csnyder@bard.edu 